\title{
Effectiveness of Disinfectants Suitable for Inactivating SARS-CoV-2 at Cold-Chain Temperature
}

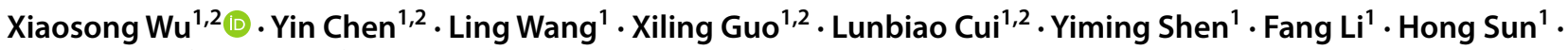 \\ Liubo Zhang ${ }^{3} \cdot$ Jin Shen ${ }^{3} \cdot$ Yan Xu ${ }^{1,2}$ (1)
}

Received: 15 October 2021 / Accepted: 11 January 2022 / Published online: 27 January 2022

(c) The Author(s), under exclusive licence to Springer Science+Business Media, LLC, part of Springer Nature 2022

\begin{abstract}
To prevent the spread of SARS-CoV-2 in cold-chain transportation in China, we developed specific cryogenic disinfectants. Carrier tests were performed against SARS-CoV-2 at $-20^{\circ} \mathrm{C}$ for the four cryogenic disinfectants developed and qRT-PCR was used to test the virus RNA. Peracetic acid, chlorine disinfectants (two different concentrations), and quaternary ammonium disinfectant with their antifreeze can all inactivate SARS-CoV-2 in $5 \mathrm{~min}$ at $-20^{\circ} \mathrm{C}$. However, after $2-3 \mathrm{~h}$ of exposure, only chlorine disinfectant could destroy SARS-CoV-2 RNA. The viruses treated with peracetic acid and quaternary disinfectants showed positive $C t$ values even after $3 \mathrm{~h}$ detected with qRT-PCR. The conclusion was that the cold-chain disinfectants we tested could inactivate SARS-CoV-2 quickly and effectively, but only chlorine disinfectants could destroy nucleic acids in $3 \mathrm{~h}$. Our study also illustrated that using qRT-PCR detection of viral nucleic acids to assess disinfection was inappropriate.
\end{abstract}

Keywords SARS-CoV-2 $\cdot$ Cryogenic disinfectants $\cdot$ Cold chain $\cdot$ Viral nucleic acids · Inactivate

\section{Introduction}

SARS-CoV-2 has caused over 238 million confirmed cases, including more than 4.8 million deaths worldwide (WHO, 2021a). Although China has effectively controlled the epidemic of COVID-19, small-scale outbreaks continue to occur in some cities (Chen et al., 2020; Xu et al., 2020). Field epidemiological evidence suggests that SARS-CoV-2 can survive on the outer packaging of cold-chain foods kept in a low-temperature environment, such as in the outbreak in Qingdao, China (Liu et al., 2020). Transmission of SARS$\mathrm{CoV}-2$ via the cold chain may present a route of infection

Xiaosong Wu, Yin Chen, Ling Wang and Xiling Guo have contributed to this paper equally.

Yan Xu

cdcxy@vip.sina.com

1 Jiangsu Provincial Center for Disease Control and Prevention, 172 Jiangsu Road, Nanjing 210009, Jiangsu, China

2 National Health Committee Key Laboratory of Enteric Pathogenic Microbiology, 172 Jiangsu Road, Nanjing 210009, China

3 National Institute of Environmental Health, Chinese Center for Disease Control and Prevention, Beijing 100021, China in humans (WHO, 2021b). After restricting the movement of people during a pandemic, the spread of SARS-CoV-2 through the cold chain should not be ignored either, because the virus can survive for a long duration at low temperatures (Chin et al., 2020) and has been proved not to lose infectivity (Han et al., 2020; Liu et al., 2020).

Although the WHO recommended many disinfectants that can effectively kill SARS-CoV-2, temperatures below $0{ }^{\circ} \mathrm{C}$ might render these regular disinfectants ineffective by freezing them. To effectively kill the SARS-CoV-2 at low temperatures, we developed some freeze-resistant disinfectants and evaluated their ability to inactivate the virus in low-temperature environments. To understand disinfectants' destruction of the viral genetic structure, we also examined nucleic acids of SARS-CoV-2 after inactivation experiments.

\section{Materials and Methods}

SARS-CoV-2 strain (SARS-CoV-2/human/CHN/Changzhou_JS27/2020, GENEBANK NO. MT534630) was used to test four disinfectants mixed with different antifreeze ingredients. As shown in Table 1, the disinfectants used in the study were peracetic acid (mixed with ethanol) (Liu et al., 2004), chlorine disinfectant (trichloroisocyanuric 
Table 1 Chemical information of disinfectant with antifreeze and its neutralizer

\begin{tabular}{|c|c|c|c|c|c|}
\hline Disinfectant (manufacturer) & Active ingredient & Antifreeze ingredient & $\begin{array}{l}\text { Ratio (disinfect- } \\
\text { ant: antifreeze, } \\
\mathrm{v} / \mathrm{v} \text { ) }\end{array}$ & $\begin{array}{l}\text { Final concentra- } \\
\text { tion after mixed }\end{array}$ & Neutralizer \\
\hline $\begin{array}{l}\text { Peracetic acid (Beijing } \\
\text { Changjiangmai Medical } \\
\text { Science Technology Co., } \\
\text { Ltd, Beijing, China) }\end{array}$ & Peracetic acid (PA) & Ethanol & $2: 1$ & $2000 \mathrm{mg} / \mathrm{L}$ & $\begin{array}{l}2 \mathrm{~g} / \mathrm{L} \text { sodium } \\
\text { thiosulfate }+2 \mathrm{~g} / \mathrm{L} \\
\text { lecithin }\end{array}$ \\
\hline \multirow{2}{*}{$\begin{array}{l}\text { Chlorine disinfectant } \\
\text { (Beijing Changjiangmai } \\
\text { Medical Science Technol- } \\
\text { ogy Co., Ltd, Beijing, } \\
\text { China) }\end{array}$} & \multirow[t]{2}{*}{$\begin{array}{l}\text { Trichloroisocyanuric acid } \\
\text { (TA) }\end{array}$} & \multirow[t]{2}{*}{ Ethylene glycol } & \multirow[t]{2}{*}{$1: 1$} & $1000 \mathrm{mg} / \mathrm{L}^{\mathrm{a}}$ & $\begin{array}{l}1 \mathrm{~g} / \mathrm{L} \text { sodium } \\
\text { thiosulfate }+1 \mathrm{~g} / \mathrm{L} \\
\text { lecithin }\end{array}$ \\
\hline & & & & $2000 \mathrm{mg} / \mathrm{L}^{\mathrm{a}}$ & $\begin{array}{l}2 \mathrm{~g} / \mathrm{L} \text { sodium } \\
\text { thiosulfate }+2 \mathrm{~g} / \mathrm{L} \\
\text { lecithin }\end{array}$ \\
\hline $\begin{array}{l}\text { Quaternary ammonium salt } \\
\text { (Guangdong Weng Jiang } \\
\text { Reagent Co., Ltd, Shao- } \\
\text { guan City, Guangdong, } \\
\text { China) }\end{array}$ & $\begin{array}{l}\text { Di- } N \text {-decyldimethylammo- } \\
\text { nium chloride (DNC) }\end{array}$ & Ethanol & $2: 1$ & $3000 \mathrm{mg} / \mathrm{L}$ & $\begin{array}{l}2 \mathrm{~g} / \mathrm{L} \text { sodium } \\
\text { thiosulfate }+2 \mathrm{~g} / \mathrm{L} \\
\text { lecithin }\end{array}$ \\
\hline
\end{tabular}

${ }^{\mathrm{a} C}$ Concentrations of available chlorine

acid, mixed with ethylene glycol) with two concentrations (Liu et al, 2008), Quaternary ammonium salt (Di$\mathrm{N}$-decyldimethylammonium chloride, DNC, mixed with ethanol). The virus suspension (with the viral titers of $10^{5.50} / 0.1 \mathrm{~mL}$ ) prepared according to our published manuscript (Guo et al., 2021) was divided into sterile cloth carriers (white plain cotton cloth, $10 \mathrm{~mm} \times 10 \mathrm{~mm}$ ) (NHC China, 2021) at $10 \mu \mathrm{L}$ per carrier and placed to dry naturally. Viral titers were calculated by expressing them as the $50 \%$ tissue culture infective dose $\left(\mathrm{TCID}_{50}\right)$. We used the cloth carrier containing SARS-CoV-2 (TCID $_{50}: 10^{4.00} /$ carrier) to expose to disinfectants with specific antifreeze at $-20{ }^{\circ} \mathrm{C}$. An appropriate neutralizer for each disinfectant was selected by conducting a test according to Technical Standard for Disinfection (MH China, 2002).

Quantitative carrier tests were used to evaluate the disinfection effect of cryogenic disinfectants against SARS$\mathrm{CoV}-2$ at $-20{ }^{\circ} \mathrm{C}$. Carriers stored at $-20^{\circ} \mathrm{C}$ for more than 60 min were soaked in different cryogenic disinfectants stored at $-20^{\circ} \mathrm{C}$. The entire disinfection process was carried out in an ethanol bath at $-20{ }^{\circ} \mathrm{C}$ (JULABO GmbH, Seelbach, Germany). After exposure, the carriers were removed from the disinfectant and mixed in the neutralizer solution for $10 \mathrm{~min}$. The positive control used sterile deionized water instead of disinfectant at room temperature. Negative control used cloth carrier without virus and cell maintenance solution at room temperature too. The carrier was eluted by shaking on a vortex oscillator. Samples were seeded onto cell culture plates at the time point $5,10,20$ and $30 \mathrm{~min}$. Viral titers were determined for each carrier, and TCID $_{50}$ and $\log _{10}$ inactivation were calculated according to our published manuscript (Guo et al., 2021). The test was repeated in three replicates.
After neutralization, the virus RNA was extracted from samples by the kits (NP968, Tianlong Science \& Technology, Xi-An, China) and real-time RT-PCR was performed (ABI QuantStudio Dx, Thermo Fisher Scientific, Waltham, MA, USA). The virus detection kit was from Shanghai Wuseshi Medical Research Co. Ltd. These samples' nucleic acid was extracted and amplified by qRT-PCR from 5 to $180 \mathrm{~min}$. We tested them for the open reading frame $1 \mathrm{ab}$ (ORF1 ab) and nucleoprotein (N) genes of SARS-CoV-2. A sample was defined as positive at a $C t \leq 37$. The test was repeated in three replicates. The $C t$ value data analyses were performed using Excel software (Version 2010, Microsoft, USA).

\section{Results and Discussion}

As shown in the supplementary table, all these four cryogenic disinfectants could inactivate SARS-CoV-2 (4 $\log _{10}$ reductions) in $5 \mathrm{~min}$ in an ethanol bath at $-20^{\circ} \mathrm{C}$.

As shown in Fig. 1, the Cycle-threshold $(C t)$ value for the ORF1ab gene of trichloroisocyanuric acid (available chlorine $2000 \mathrm{mg} / \mathrm{L}$ ) exceeded 37 at $120 \mathrm{~min}$, faster than trichloroisocyanuric acid (available chlorine $1000 \mathrm{mg} / \mathrm{L}$ ), which need $180 \mathrm{~min}$. Similarly, the $C t$ value for the $\mathrm{N}$ gene of trichloroisocyanuric acid (available chlorine $2000 \mathrm{mg} / \mathrm{L}$ ) reached 37 at $120 \mathrm{~min}$, and trichloroisocyanuric acid (available chlorine $1000 \mathrm{mg} / \mathrm{L}$ ) exceeded 37 at $180 \mathrm{~min}$.

Peracetic acid and DNC could not completely destroy the RNA of SARS-CoV-2 throughout the 180-min experiment (Fig. 1). After $180 \mathrm{~min}$ of experimental exposure, the $C t$ value for ORF1ab gene of SARS-CoV-2 treated by peracetic acid and DNC were $28.8 \pm 0.1$ and $33.5 \pm 0.3$, respectively; 


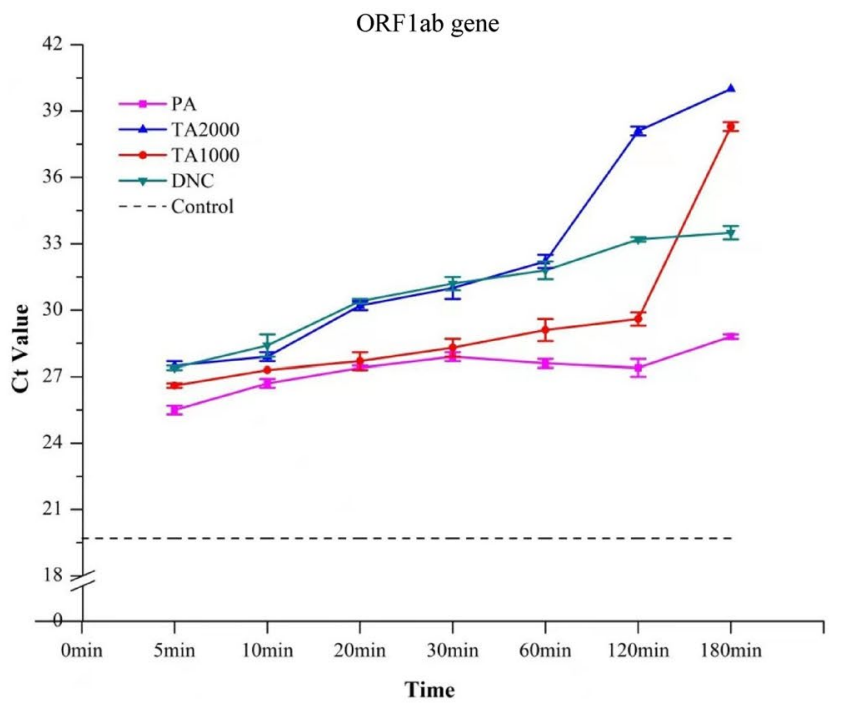

Fig. $1 C t$ value for ORF1ab and $\mathrm{N}$ genes of four cryogenic disinfectants on SARS-CoV-2 inactivation at $-20{ }^{\circ} \mathrm{C}$ at different time point. As shown in Figure, $C t$ value showed the ORF1ab and $\mathrm{N}$ genes of SARS-CoV-2 nucleic acid tested result by qRT-PCR, which were inactivated by peracetic acid (PA), trichloroisocyanuric acid (TA2000, available chlorine $2000 \mathrm{mg} / \mathrm{L}$ ), trichloroisocyanuric acid

the $C t$ value for the $\mathrm{N}$ gene was $27.0 \pm 0.2$ and $31.0 \pm 0.0$ after exposure of $180 \mathrm{~min}$, respectively.

Considering the low temperature in the cold-chain environment, we used the cryogenic disinfectants (peracetic acid and chlorine disinfectant with two concentrations) according to previous research (Liu et al, 2004, 2008) and raised the concentration of active ingredients of DNC disinfectant (compare to our research Guo et al., 2021), which also added antifreeze. For the first time, our results showed that cryogenic disinfectants could inactivate SARS-CoV-2 in a short time at $-20^{\circ} \mathrm{C}$, which is consistent with the results of other studies conducted at room temperature (Ogilvie et al., 2021). The difference is that fewer concentrations and exposure time were needed to inactivate SARS-CoV-2 at room temperature (Guo et al., 2021).

In early studies discussing the risk of hospital infection related to the environment, RNA of SARS-CoV-2 was widely used as a marker of environmental contamination because of its convenience and quickness (Ong et al., 2020; Razzini et al., 2020). It was also commonly used for SARSCoV-2 contamination testing of cold-chain goods (Liu et al., 2020). Therefore, there was a misconception that the detected SARS-CoV-2 nucleic acid fragment was equivalent to an infectious virus in the environment. Some other studies have also attributed the detection of SARS-CoV-2 RNA after disinfection to the selection of the wrong disinfection method or disinfectant (Hu et al., 2020).

Our results suggested that the destruction of SARSCoV-2 RNA by disinfectants needed at least $2-3 \mathrm{~h}$. The

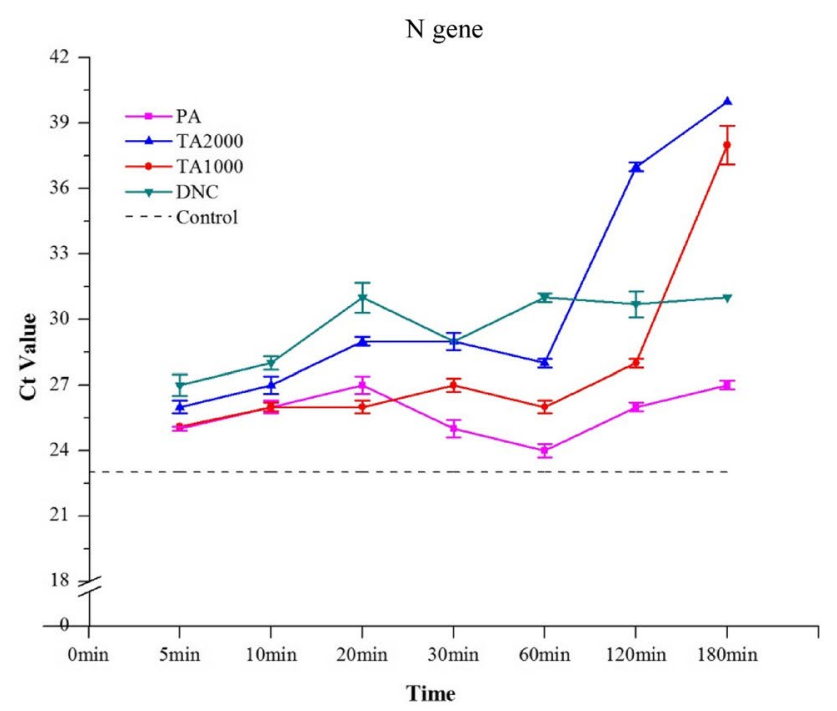

(TA1000, available chlorine $1000 \mathrm{mg} / \mathrm{L}$ ) and Di- $N$-decyldimethylammonium chloride (DNC) with their own antifreeze at $-20{ }^{\circ} \mathrm{C}$ from 5 to $180 \mathrm{~min}$. Plots show the means and standard error (I bars) across three replicates. The dashed lines indicate the $C t$ value of the positive control, which were $19.7 \pm 0.2$ per carrier (ORF1ab) and 23.0 \pm 0.0 per carrier $(\mathrm{N})$ for these four cryogenic disinfectants, respectively

results from qRT-PCR showed that the RNA was not destroyed until $2-3 \mathrm{~h}$ by a chlorine disinfectant with different concentrations. The RNA remained positive $(C t \leq 37)$ throughout the $3 \mathrm{~h}$ experiment of the other two disinfectants. These results were consistent with the mechanism of action of the different disinfectants on the virus. Hypochlorite produced by chlorine disinfectant can destruct virus RNA by the formation of chloramines and nitrogen-centered radicals (Hawkins \& Davies, 2002). Differently, peracetic acid does not readily damage viral genomes, although it effectively inactivates viruses by targeting susceptible amino acids on capsid proteins (Schmitz et al., 2021). Similarly, the main target of quaternary ammonium salt is the virally modified, host-cell-derived, phospholipid bilayer glycoproteinaceous envelope (Cegolon et al., 2020).

The result of qRT-PCR of the environmental sample should not be used to evaluate the inactivation effect of SARS-CoV-2 after disinfection in a low-temperature environment. SARS-CoV-2 nucleic acid cannot be destroyed in $10 \mathrm{~min}$ [prescribed disinfection time in guidelines for the use of two chlorine-containing low-temperature disinfectants (NHC China, 2021)], which is far less than the time (2-3 h) in our study. If a positive SARS-CoV-2 nucleic acid was considered a disinfection failure, then repeated disinfection would be unavoidable, which could lead to over-disinfection.

The strength of this study was that we first reported four effective cryogenic disinfections and evaluated their effectiveness on SARS-CoV-2. The main limitation was that we could not reduce the exposure time to less than $5 \mathrm{~min}$, 
considering the biosafety in the BSL-3 lab and the ethanol bath needs enough time to balance. Because of the differences between cloth carriers and true cold-chain overwrapping materials, our results may not be exactly the same as cold-chain disinfection practices.

In conclusion, peracetic acid (mixed with ethanol), chlorine disinfectant (trichloroisocyanuric acid, mixed with ethylene glycol) with two concentrations and quaternary ammonium salt (DNC, mixed with ethanol) can inactivate SARS-CoV-2 on the cold chain's surface. The RNA of SARS-CoV-2 remained detectable in 2-3 h disinfection, even if disinfectants fully inactivated the virus in $5 \mathrm{~min}$. Our finding suggested that it was necessary to find another way besides qRT-PCR to evaluate the disinfection on SARS$\mathrm{CoV}-2$, especially in the cold chain or low temperature.

Supplementary Information The online version contains supplementary material available at https://doi.org/10.1007/s12560-022-09509-0.

Author Contributions YX, XG, and XW proposed the research and directed the study. YC and LW carried out a virus disinfection experiment. YS and FL contributed to technical or material support. XW, LC and HS analyzed the data and prepared the manuscript. LZ and JS revised the manuscript critically. XW, YC, LW and XG contributed equally to this manuscript.

Funding This work was supported by the National Science and Technology Major Project (2018ZX10734401-006), the Jiangsu Provincial Commission of Health (CXTDB2017012, ZDA2020015, LGY2019074, K2019008), the National Natural Science Foundation of China (91743205), and the Jiangsu Social Development Project (BE2018745).

Data Availability The data generated during and/or analyzed during the current study are included in this published article and additional information are available from the corresponding author on reasonable request.

\section{Declarations}

Conflict of interest The authors declare they have no actual or potential competing financial interests.

\section{References}

Cegolon, L., Javanbakht, M., \& Mastrangelo, G. (2020). Nasal disinfection for the prevention and control of COVID-19: A scoping review on potential chemo-preventive agents. International Journal of Hygiene and Environmental Health, 230, 113605.

Chen, C., Zhao, X., Wang, D., Li, J., Wang, A., Wu, D., et al. (2020). The initial case of COVID-19-Shulan City, Jilin Province, China, May 8, 2020. China CDC Weekly, 2(25), 458-459.

Chin, A., Chu, J., Perera, M., Hui, K., Yen, H. L., Chan, M., et al. (2020). Stability of SARS-CoV-2 in different environmental conditions. The Lancet Microbe, 1(1), e10. https://doi.org/10.1016/ S2666-5247(20)30003-3
Guo, X. L., Chen, Y., Wang, L., Wu, X. S., Fan, J. J., Li, F., et al. (2021). In vitro inactivation of SARS-CoV-2 by commonly used disinfection products and methods. Scientific Reports, 11(1), 2418.

Han, J., Zhang, X., He, S., \& Jia, P. (2020). Can the coronavirus disease be transmitted from food? A review of evidence, risks, policies and knowledge gaps. Environmental Chemistry Letters, 19(1), $5-16$.

Hawkins, C. L., \& Davies, M. J. (2002). Hypochlorite-induced damage to DNA, RNA, and polynucleotides: Formation of chloramines and nitrogen-centered radicals. Chemical Research in Toxicology, 15(1), 83-92.

Hu, X., Xing, Y., Ni, W., Zhang, F., Lu, S., Wang, Z., et al. (2020). Environmental contamination by SARS-CoV-2 of an imported case during incubation period. The Science of the Total Environment, 742, 140620.

Liu, P., Yang, M., Zhao, X., Guo, Y., Wang, L., Zhang, J., et al. (2020). Cold-chain transportation in the frozen food industry may have caused a recurrence of COVID-19 cases in destination: Successful isolation of SARS-CoV-2 virus from the imported frozen cod package surface. Biosafety and Health, 2(4), 199-201.

Liu, T., Lei, S., \& Wang, Y. (2008). Research on antifreezing compounds for the chlorine-containing disinfectants. Chinese Journal of Disinfection, 25(4), 377-379.

Liu, X., Chen, C., Li, D., Liu, G., \& Wang, Y. (2004). Experimental study on peracetic acid low temperature disinfection. Chinese Journal of Disinfection, 21(4), 327-328.

Ministry of Health, China (MH China). (2002). Technical standard for disinfection. Ministry of Health, China (MH China).

National Health Commission, China (NHC China). (2021). Guidelines for the use of two chlorine-containing low-temperature disinfectants. http://www.nhc.gov.cn/jkj/s7934td/202102/bad278a7bc 344112ae3e88d7e1b4207c.shtml

Ogilvie, B. H., Solis-Leal, A., Lopez, J. B., Poole, B. D., Robison, R. A., \& Berges, B. K. (2021). Alcohol-free hand sanitizer and other quaternary ammonium disinfectants quickly and effectively inactivate SARS-CoV-2. The Journal of Hospital Infection, 108, $142-145$.

Ong, S., Tan, Y. K., Chia, P. Y., Lee, T. H., Ng, O. T., Wong, M., et al. (2020). Air, surface environmental, and personal protective equipment contamination by severe acute respiratory syndrome coronavirus 2 (SARS-CoV-2) from a symptomatic patient. JAMA, 323(16), 1610-1612.

Razzini, K., Castrica, M., Menchetti, L., Maggi, L., Negroni, L., Orfeo, N. V., et al. (2020). SARS-CoV-2 RNA detection in the air and on surfaces in the COVID-19 ward of a hospital in Milan, Italy. The Science of the Total Environment, 742, 140540.

Schmitz, B. W., Wang, H., Schwab, K., \& Jacangelo, J. (2021). Selected mechanistic aspects of viral inactivation by peracetic acid. Environmental Science \& Technology. https://doi.org/10.1021/acs.est. $1 \mathrm{c} 04302$

WHO. (2021b). WHO-convened Global Study of Origins of SARSCoV-2: China part. https://www.who.int/publications/i/item/whoconvened-global-study-of-origins-of-sars-cov-2-china-part

WHO. (2021a). Coronavirus disease (COVID-19) dashboard. https:// covid19.who.int/.

Xu, J., Zhang, Y., Zhao, X., Wang, D., Dai, W., Jiao, G., et al. (2020). A reemergent case of COVID-19-Harbin City, Heilongjiang Province, China, April 9, 2020. China CDC Weekly, 2(25), 460-462.

Publisher's Note Springer Nature remains neutral with regard to jurisdictional claims in published maps and institutional affiliations. 